\title{
Capacity building for effective municipal environmental management in South Africa
}

\author{
T. C. Meyer \& E. le Roux \\ Centre for Environmental Management, North-West University, \\ South Africa
}

\begin{abstract}
Sustainable urban management and development is a critical issue for the $21 \mathrm{st}$ century that needs to be addressed by strong, decentralized local governments. The pervasive weakness of local governments and the lack of capacity of municipal institutions are major impediments to sustainable development and require capacity building initiatives at various levels. This paper discusses a municipal environmental management capacity building programme in the Mpumalanga province of South Africa. It provides details of the municipalities, the municipal environmental management function, officials and councillors that participated, as well as environmental management initiatives in participant municipalities. Norms for quality education that was adhered to during the programme are also discussed. Programmes like these can go a long way towards improving the environmental management capacity in local authorities, enabling them to address relevant issues effectively. The success of sustainable development initiatives depend on the way municipal management, their partners and other spheres of government, act coherently and with common purpose in addressing specific local challenges.

Note: when used in this article, sustainable development means the integration of social, economic and environmental factors into planning, implementation and decision-making so as to ensure that development serves present and future generations. Environmental management refers to the management of human activities to mitigate actual or prevent potential impacts on the environment. In relation to sustainable development, it only focuses on environmental factors.

Keywords: urban environmental management, capacity building, training programme, participants, sustainable development.
\end{abstract}




\section{Introduction}

South Africa's transformation started off with a political change in 1994 and is proceeding with a transformation of all spheres and levels of society, economy and governance. As a result, there is no clear understanding of municipal environmental management activities or the people involved. This study was undertaken to provide a better understanding of these activities and individuals.

\subsection{Improving urban governance}

With half of the world's population living in urban settlements, the issue of sustainable urban management and development is one of the critical issues for the 21 st century (WSSD [1]). Urban areas produce a series of environmental problems arising from the consumption of natural resources and the consequent generation of pollution and waste. These problems contribute to the development of social and economic imbalances in urban societies. How governments and communities meet the concurrent challenges of rapid urbanization, poverty, development, and protection of the natural environment will largely determine the world's future.

Better local governance is a key to meeting urban challenges. There is growing consensus globally that national governments cannot manage and control complex cities and towns. Only strong, decentralized local governments, in touch with and involving their citizens and working in partnership with national governments, are in a position to do so (WSSD [1], HABITAT [2]).This is also echoed by Agenda 21, a comprehensive plan of action to be implemented in every area in which humans impact on the environment (UNCED [3]).

Shifting authority from central governments to municipalities can help make policies, plans, and actions more responsive, especially to the urban poor (Hinrichsen et al. [4]). National governments should move towards playing the role of the enabler, while local governments move towards more direct control over the planning and management of urban areas. To enable local governments to perform these new functions, national governments need to devolve budget authority and resources to the municipal level, enhance the administrative capacity of local governments and promote public participation, particularly by local community members (HABITAT [2], HABITAT [5], World Bank [6]).

South Africa is a unitary state consisting of three distinct, interrelated and interdependent spheres of government - national, provincial and local. Cities and towns form part of a developmental system of local government that is made up of six metropolitan municipalities and 47 district municipalities (containing 231 local municipalities) that cover the entire geographical area of the country. Cities and towns are viewed as spaces in which the three spheres of government have to take on joint responsibility to ensure the overall success of urban functionality and efficiency. The extent, to which sustainable development is achieved, depends on the way municipal management, together with other spheres of government and partners, act coherently and with common purpose in addressing specific local challenges (Patel [7]). 


\subsection{Lack of capacity}

Local government needs to be both efficient and effective in carrying out programmes that tackle the challenges of equitable and sustainable development. Doing so requires the ability to analyse social, environmental and economic situations, as well as the ability to create creative solution with partners and to communicate effectively with decision-makers. Decision-makers further need the knowledge and ability to set priorities and to work for medium- and long term, as well as short-term objectives (HABITAT [5]).

The pervasive weakness of local governments and the lack of capacity of municipal institutions in sub-Saharan Africa is a major impediment to sustainable development. This means that capacity building to manage problems at various levels of government is vital to any sustainable development (World Bank [6]). Therefore, training must encompass local government, as well as its partners and be aimed at council members, as well as officials (HABITAT [5]).

In South Africa, environmental management is an area of concurrent jurisdiction for national, provincial and local governments. Although much effort has been put into developing environmental legislative and policy systems since 1994, more activity needs to be devolved to the local and provincial levels, according to the SA Human Rights Commission [8]. Energies and resources need to be concentrated at these levels to facilitate implementation. Capacitating municipalities in environmental management and conservation issues should be a priority of the national and provincial governments, in line with the Constitution.

\subsection{Capacitating people for sustainable development}

Capacity-building has been one of the central notions in the sustainable development agenda since the introduction of the concept in the Brundlandt report and has a particular prominent place in contemporary environmental policy-making. It was identified as the principal 'means of implementation' for most of the programme areas of the 1992 Rio Earth Summit Agenda 21 agreement, and as such it has become a crucial element in LA21 programmes worldwide and other initiatives for sustainable development (Evans et al. [9]).

According to Chapter 37 of Agenda 21, the ability of a country to follow sustainable development paths is to a large extent determined by the capacity of its people and its institutions. A fundamental goal of capacity building is to enhance the ability to evaluate and address the crucial questions related to policy options and modes of implementation among development options (UNCED [3]).

Evans et al. [9] argues that capacity-building is usually understood as $a$ process that strengthens the ability of local communities and organisations to build their structures, systems, people and skills in order to undertake and develop initiatives that will contribute to sustainable development.

As a concept, capacity-building clearly goes beyond the training of individuals to the strengthening of the institutions and frameworks within which they work (HABITAT [5]). The United Nations Development Programme's (UNDP's) Capacity 21 programme understands capacity-building as the 'sum of all efforts needed to nurture, enhance and utilise the skills of people and 
institutions to progress towards sustainable development' (UNDP [10]. Sustainable development capacity-building can be defined as all measures that strengthens the governmental structures to meet the demand of sustainable development, as well as measures that create these capacities in cooperation with civil society (Evans et al. [9]).

\section{Municipal environmental management capacity building}

The Mpumalanga Department of Agriculture and Land Administration (DALA), through its interactions and co-operation with important role players, identified the need to strengthen the capacity of municipalities so that they can play a meaningful and constructive role in environmental management and sustainable development in the Mpumalanga Province. In association with the Centre for Environmental Management (CEM), DALA developed the environmental management training programme for municipalities.

The aim of the capacity building programme was to provide municipalities with a basic theoretical understanding of environmental management. The programme consisted of nine modules (courses), 3 to 5 days long, which was presented between July 2004 and October 2005. A total of 91 people from 20 local and 5 district municipalities participated in the training programme. A core group of 28 participants attended more than six modules, while 43 attended less than four modules. An average of 42 participants attended each module.

\subsection{Profile of participating municipalities}

The context within which the programme was delivered is provided by this short profile of the participating local municipalities $(n=20)$, focussing on a few key characteristics (Table 1).

Table 1: Key characteristics of municipalities that participated in the programme (Gaffney [11]).

\begin{tabular}{|l|c|c|}
\hline \multicolumn{1}{|c|}{ Characteristic } & $\begin{array}{c}\text { Average ( } \pm \text { standard } \\
\text { deviation) }\end{array}$ & Range \\
\hline Area $\left(\mathrm{km}^{2}\right)$ & $3253( \pm 1385)$ & $1415-5105$ \\
\hline Population size & $177284( \pm 87752)$ & $43007-474806$ \\
\hline Population density $\left(/ \mathrm{km}^{2}\right)$ & $66.1( \pm 47.1)$ & $10-194$ \\
\hline Urban $(\%$ of population) & $42.1( \pm 31.2)$ & $1.1-93$ \\
\hline Rural $(\%$ of population) & $57.9( \pm 31.2)$ & $7-98.9$ \\
\hline Electricity (\% access) & $54.2( \pm 18.0)$ & $54-93$ \\
\hline Water $(\%$ access) & $77.6( \pm 12.6)$ & $71-98$ \\
\hline Sanitation $(\%$ access) & $88.8( \pm 8.9)$ & $38.2-472.8$ \\
\hline $\begin{array}{l}\text { Operational budget (ZAR } \\
\text { million) }\end{array}$ & $154.5( \pm 140.0)$ & $5.7-203.0$ \\
\hline Capital budget (ZAR million) & $51.6( \pm 47.5)$ & \\
\hline
\end{tabular}




\subsection{Profile of municipal environmental management activities in participating municipalities}

Municipal managers in Mpumalanga were requested to nominate participants to the training programme. Participants $(n=74)$ were classified into 8 distinct and relative uniform functions, according to their job titles. Figure 1 reflects the functional (departmental) affiliation of the total number of individual participants that were nominated, while Figure 2 reflects the percentage of municipalities with participants from the various functional (departmental) affiliations.

The environmental health function in municipalities were best represented during the programme, with $25 \%$ of all individuals coming from this function, while $65 \%$ of all municipalities nominated a participant from this function. Other functions that were also well represented were community services $(15 \%$ of individuals and nearly $40 \%$ of municipalities), IDP (12\% of individuals and more than $30 \%$ of municipalities). It is interesting to note the active participation of elected politicians (councillors) as the second largest group (22\% of individuals and nearly $70 \%$ of municipalities). Although not indicated in the figures, 16 officials from the DALA also attended the training programme.

Municipal environmental management is primarily responsible for protecting, respecting, promoting and fulfilling the rights of the people in the municipality to an environment that is not harmful to their health or well-being. On the one hand, it entails activities classified as municipal health functions, i.e. water quality monitoring, waste management (cleansing, refuse removal, refuse dumps and solid waste disposal), vector control, control of environmental pollution, disposal of the dead and chemical safety.

On the other, it includes activities related to other functions such as the control of air pollution, noise pollution, water and sanitation services (potable water supply, domestic waste-water and sewage disposal systems), municipal planning, fire fighting services, municipal public works (buildings and facilities needed to administer assigned functions), storm water management systems in

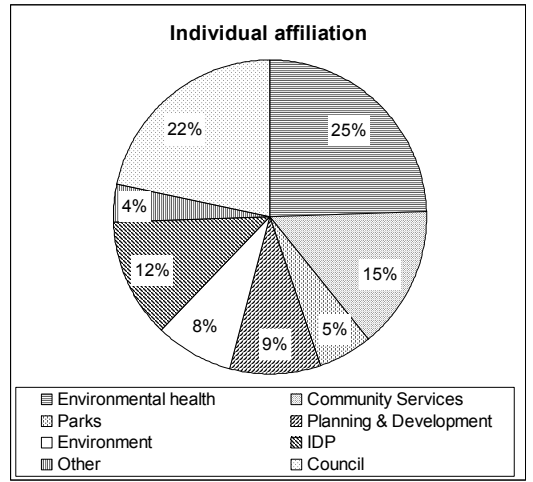

Figure 1: Functional affiliation of individual participants.

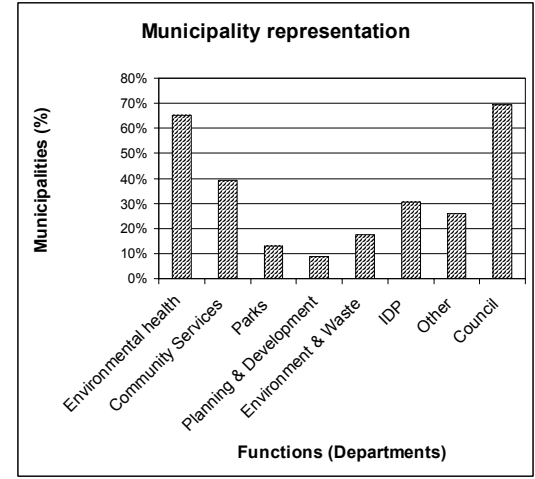

Figure 2: Functional representation of municipalities. 
built-up areas, municipal parks and recreation, beaches and amusement facilities, cemeteries, funeral parlours and crematoria, local amenities, billboards and the display of advertisements in public places, local sport facilities, control of public nuisances, facilities for the accommodation, care and burial of animals, pounds, licensing of dogs, fencing and fences, markets, municipal abattoirs, municipal roads, public places, street trading, street lighting, traffic and parking (South Africa [12]). It is clear that various functions (departments) in municipalities are involved in municipal environmental management.

\subsection{Participant profile}

Participants in the programme were classified according to gender $(n=90)$, age $(n=67)$, population group $(n=90)$, formal study $(n=52)$, work experience $(n=53)$ and organisational responsibility (executive [councillors], managerial [line managers], operational [officers] $(n=90)$. The gender, age and population group profiles of individual participants is reflected in Figure 3, while Figure 4 reflects their formal qualifications, work experience and organisational responsibility profiles.

The majority of participants were young African males, between ages 30 and 40. The gender distribution shows an inequality to females, while the population group distribution reflects the population groups of the province fairly well. The participants seem to be fairly mature with an average age of approximately 39 years. Furthermore, $47 \%$ of participants fell in the 30 to 40 age category, while $40 \%$ were older than 40 years.

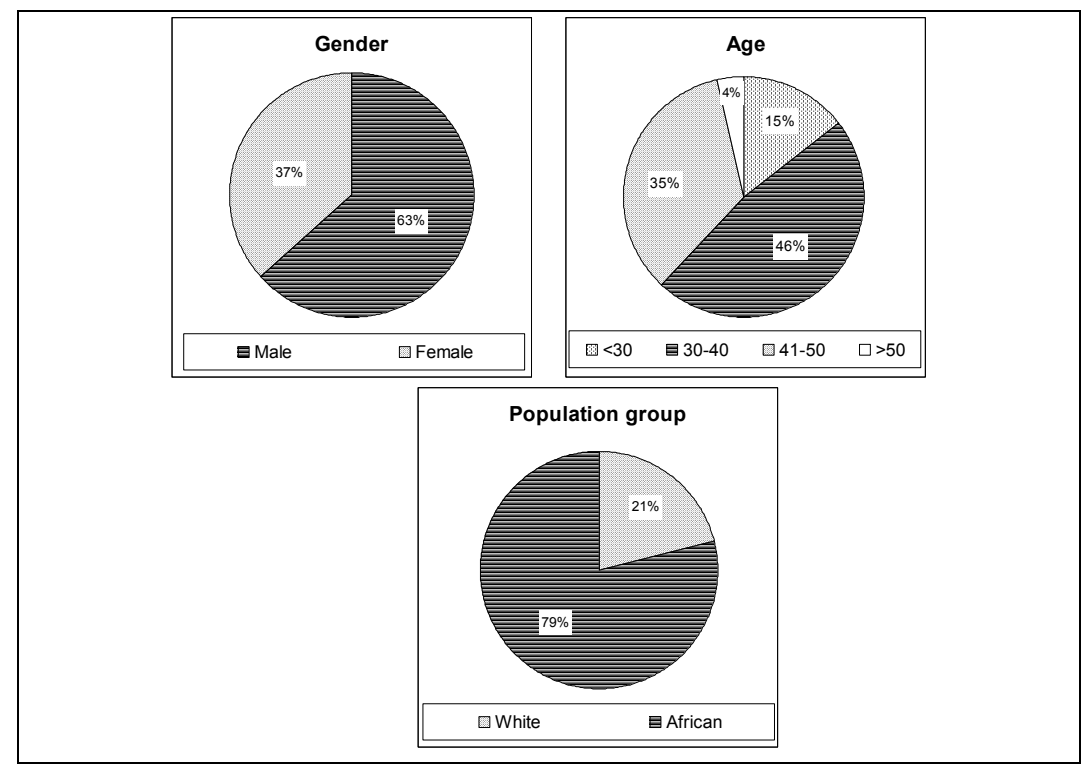

Figure 3: Gender, age and population group profiles of participants. 


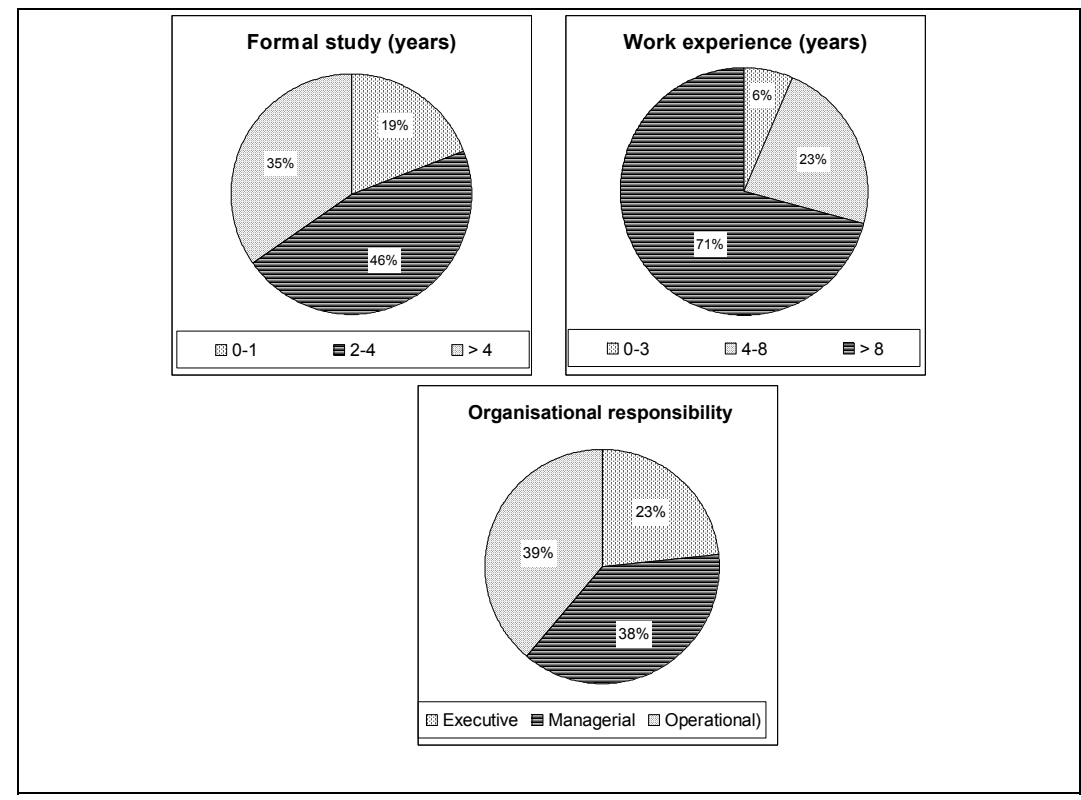

Figure 4: Formal study, work experience and organisational responsibility profile of participants.

On average, delegates had 3.6 years formal education and 13.5 years working experience. It is interesting to note that nearly $20 \%$ of delegates had no or limited formal education (less than 2 years), the majority of these being councillors, while more than a third had more than 4 years formal education. Environmental health (30\%) and education (26\%) were the most common fields of study, while more than $25 \%$ of participants also studied nature conservation/horticulture or public/general management. The majority of participants $(50 \%)$ had been active in the labour market for 5 to 15 years, while $33 \%$ had more than 15 years work experience and only $17 \%$ had been working for less than 5 years.

\subsection{Quality of training programme}

The following internationally accepted norms (characteristics) for high quality education were addressed during the development and delivery of the training programme:

- Interdisciplinary and holistic:

Although the focus of the programme was on dealing with environmental issues, social and economical aspects were embedded in the curriculum. This was mandated by the legal definition of the environment in the South African National Environmental Management Act (NEMA), No. 107 of 1998 that includes the physical, chemical, aesthetic and cultural properties 
and conditions of the surroundings within which humans exist (land, water, atmosphere; micro-organisms, plant and animal life; any part or combination of these and the interrelationships among and between them) that influence human health and well-being. It was also supported by the sustainable development principles in the said act and the emphasis in the South African society and municipal management on social and economic development;

- Value-driven:

The NEMA, apart from stating that "development must be socially, environmentally and economically sustainable", explicitly spells out eight shared values and principles underpinning sustainable development that were examined, debated, tested and applied throughout the training;

- Critical thinking and problem solving:

Participants were exposed to practical case studies, either in the classroom or through site visits, to facilitate the internalisation of the concepts. They were challenged to not only identify the challenges of sustainable development, but also to suggest some solutions to these, thereby building their confidence to address similar issues in their own municipalities;

- Multi-method:

Wherever possible, the learning programme was structured to be highly interactive and participative, enabling facilitators and learners to work together to acquire knowledge and find solutions;

- Participatory decision-making:

Although the learners themselves did not participate in decisions on how they were to learn, all modules were discussed between DALA and the CEM and customised to address specific needs and learn from local case studies;

- Applicability:

Municipalities were requested to nominate one councillor and one relevant senior manager to attend the programme, to allow for the integration of the learning experiences into municipal environmental management. This requires both technical managers that are able to do the necessary planning and budgeting to address environmental issues, as well as councillors that understand the extent and importance of such issues in order to mobilise council support. All participants were also constantly encouraged to integrate the learning experiences in their day to day personal life.

- Locally relevant:

Conscious efforts were made to identify opportunities for involving local facilitators and learning from Mpumalanga practical case studies. This not only illustrated concepts and practices with local examples, but also strengthened and sometimes even created links between the municipalities and other relevant role-players.

The programme also incorporated the following two important CEM policies:

- $\quad$ to sustain only a small core team of skilled specialists that is supported by a network of handpicked specialists in various relevant fields.

The programme was designed and delivered by a team of four people, but involved a total of 67 facilitators from the academic, research and private sectors, as well as all three spheres of government; 
- $\quad$ to actively promote the development of previously disadvantaged individuals into skilled environmental professionals and use them as presenters and sub-contractors.

The nine black male, six black female and 16 white female presenters sub-contracted as facilitators accounts for approximately $50 \%$ of all presenters.

\subsection{Environmental management activities in the municipalities}

Participants were regularly given the opportunity to report on activities/projects in their municipalities aimed at addressing environmental issues. A wide range of projects is undertaken by municipalities and communities, in partnerships with government departments, non-governmental organisations (NGOs) and sponsors (Table 1). These include capacity building, cleaning, gardening, recycling, waste management, storm water control and land protection and rehabilitation projects and programmes, as well as community forum initiatives. The unemployed and the youth in the community are involved in most of the projects.

\section{Conclusion}

Sustainable urban management and development is a critical issue for the $21 \mathrm{st}$ century that needs to be addressed by strong, decentralized local governments. The extent, to which sustainable development is achieved, depends on the way municipal management, together with other spheres of government and partners, act coherently and with common purpose in addressing locally specific challenges. However, the pervasive weakness of local governments and lack of capacity of municipal institutions are major impediments to sustainable development and require capacity building initiatives at various levels.

Knowledge of the profile of potential participants in training programmes is essential for the development and delivery of high quality capacity building interventions. The profile of municipal officials and councillors involved in municipal environmental management activities will assist service providers to improve customisation and better focus future similar capacity building interventions.

The experience during this intervention again highlighted the importance of the following aspects to ensure an effective capacity building programme:

- a training needs analysis to ensure that appropriate training is provided;

- good co-operation between local partners and environmental specialists is essential for the development of appropriate training material;

- customised training material should use locally known examples and incorporate as much visual material as possible;

- local conditions should be linked to global environmental problems;

- global environmental issues should be addressed at a local level;

- competent trainers that are conversant with the local conditions and customs and aware of the potential challenges and windows of opportunity. 
Table 2: $\quad$ Summary of municipal activities and projects aimed at addressing environmental issues.

\begin{tabular}{|c|c|}
\hline Activity & Description \\
\hline $\begin{array}{l}\text { Environmental awareness } \\
\text { programmes }\end{array}$ & $\begin{array}{l}\text { Talk shows, debates, workshops, seminars etc. to } \\
\text { educate the youth, ward committees and community } \\
\text { members on topics such as air pollution, illegal } \\
\text { dumping, waste minimisation and recycling, water } \\
\text { conservation and alien invader plant control. }\end{array}$ \\
\hline $\begin{array}{l}\text { Food, milk hygiene and } \\
\text { food handling interventions }\end{array}$ & $\begin{array}{l}\text { Educating food handlers, hawkers, and dairy farmers on } \\
\text { basic food and milk hygiene. }\end{array}$ \\
\hline $\begin{array}{l}\text { Cleanest school and ward } \\
\text { competitions }\end{array}$ & $\begin{array}{l}\text { Competitions to clean and beautify school premises and } \\
\text { wards. Includes Adopt-a-School and Adopt-a- } \\
\text { Community initiatives. }\end{array}$ \\
\hline Cleaning up campaigns & $\begin{array}{l}\text { Campaigns to collect litter and illegal waste. Linked to } \\
\text { poverty alleviation projects where unemployed are } \\
\text { temporarily employed to assist. }\end{array}$ \\
\hline Parks development projects & $\begin{array}{l}\text { Development of open spaces earmarked for parks into } \\
\text { sustainable community recreational facilities. Involves } \\
\text { changing illegal dumping areas into parks. }\end{array}$ \\
\hline $\begin{array}{l}\text { Tree planting and nursery } \\
\text { projects }\end{array}$ & $\begin{array}{l}\text { Growing of tree seedlings and planting indigenous trees } \\
\text { along streets, at houses and schools to promote greening } \\
\text { and create a healthy living environment. }\end{array}$ \\
\hline $\begin{array}{l}\text { Food gardens, medicinal } \\
\text { plant and community } \\
\text { orchard projects }\end{array}$ & $\begin{array}{l}\text { Providing vegetable and medicinal plant seedlings and } \\
\text { fruit trees to community members and traditional } \\
\text { healers to grow crops for own consumption. }\end{array}$ \\
\hline $\begin{array}{l}\text { Community recycling } \\
\text { projects }\end{array}$ & $\begin{array}{l}\text { Collection of used plastic bags from which bags, hats } \\
\text { and doormats are made, as well as empty glass bottles } \\
\text { that are sold to glass manufacturer. }\end{array}$ \\
\hline $\begin{array}{l}\text { Municipal recycling } \\
\text { project }\end{array}$ & $\begin{array}{l}\text { Establishment of drop in and buy-back centres. Sorted } \\
\text { waste is recycled. }\end{array}$ \\
\hline Composting project & Production of compost from biodegradable waste. \\
\hline $\begin{array}{l}\text { Integrated waste } \\
\text { management plans and } \\
\text { environmental programmes }\end{array}$ & $\begin{array}{l}\text { Development, review and implementation of plans and } \\
\text { programmes. }\end{array}$ \\
\hline Solid waste management & $\begin{array}{l}\text { Extension of refuse removal and cleansing services to } \\
\text { rural villages. }\end{array}$ \\
\hline Upgrading of land-fill sites & Fencing, upgrading and registering of landfill sites. \\
\hline Alien plant removal & $\begin{array}{l}\text { Temporary employment of community members to } \\
\text { remove alien invasive plants. }\end{array}$ \\
\hline $\begin{array}{l}\text { Wetland protection and } \\
\text { land rehabilitation projects }\end{array}$ & $\begin{array}{l}\text { Projects to protect and sustain wetlands and to } \\
\text { rehabilitate areas degraded by illegal sand mining and } \\
\text { waste disposal. }\end{array}$ \\
\hline $\begin{array}{l}\text { Construction of storm } \\
\text { water retention ponds }\end{array}$ & Control of storm water with controlled releases. \\
\hline $\begin{array}{l}\text { Environmental monitoring } \\
\text { forum }\end{array}$ & $\begin{array}{l}\text { Monitoring of industrial processes by experts. } \\
\text { Information cleared and reported. }\end{array}$ \\
\hline
\end{tabular}

The training programme successfully addressed the norms for quality education, as reflected by the feedback of participants to the programme. The 
majority of participants $(>75 \%)$ were positive with regard to the overall impression of the programme, meeting of expectations, relevance, benefits and quality of training, balance and level of the programme, as well as the training methods employed and administrative arrangements. They acknowledged that the individual courses did not only improve their general levels of knowledge, but also their ability to develop and implement appropriate initiatives.

Municipalities are involved in numerous projects and programmes addressing environmental issues. The majority of these have either been initiated by government driven programmes (e.g. the clean schools, wards and towns campaign) and poverty alleviation programmes (e.g. Land Care, Working for Water and Working for Wetlands) or by legislative requirements, such as those governing the Integrated Development Programme (IDP) process. However, these initiatives are often perceived and executed as unrelated, independent activities. Participation in the programme assisted participants to realise that all of these are focussed on addressing interrelated municipal environmental issues.

South Africa has made tremendous progress in redressing the legacy of the past and meeting the global millennium development targets. However, much more still needs to be done. Although much effort has been put into developing environmental legislative and policy systems, energies and resources now need to be concentrated at the local and provincial levels to facilitate implementation. Capacitating municipalities in environmental management and conservation issues should be a priority of the national and provincial governments in line with the Constitution. In this regard, programmes similar to the one that has been reported on could assist in building municipal environmental management capacity in South Africa.

\section{Acknowledgements}

The authors acknowledge the inputs of the staff of the Mpumalanga Department of Agriculture and Land Administration and colleagues at the Centre for Environment in the successful delivery of the programme.

\section{References}

[1] World Summit on Sustainable Development (WSSD), Local Government declaration to the World Summit on Sustainable Development. World Summit on Sustainable Development: Johannesburg, 2002.

[2] United Nations Centre for Human Settlements (HABITAT), The state of the world's cities 2001, Habitat: Nairobi, 2001.

[3] United Nations Conference on Environment and Development (UNCED), Agenda 21, Chapters 28, 36, 37, UNCED: New York, 2002.

[4] Hinrichsen, D., Salem, R. \& Blackburn, R., Meeting the urban challenge, Population Reports, Series M, Number 16, The John Hopkins Bloomberg School of Public Health: Baltimore, 2002. 
[5] United Nations Centre for Human Settlements (HABITAT), Cities in a globalizing world: Global report on human settlements 2001, Earthscan: London, p. 162, 2001.

[6] World Bank Economic Development Institute (EDI), Strengthening Local Governments in Sub-Saharan Africa, EDI Seminar Report Number 21, World Bank: Washington, D.C., 1989.

[7] Patel, Y., New Urban Realities: Overview of Urban Challenges Facing South Africa, Presentation at World Urban Forum: Barcelona, 2004.

[8] South African Human Rights Commission (SAHRC), The right to a healthy environment. 5th Economic and Social Rights Report Series, South African Human Rights Commission: Pretoria, 2004.

[9] Evans B., Joas M., Sundback S. \& Theobald K., Governing sustainable cities, Earthscan: London, pp. 23, 26, 28, 2004.

[10] United Nations Development Programme (UNDP), Capacity 21 Annual report: Local Action, National Impact, UNDP: New York, 1999.

[11] Leon, J (ed.), Gaffney's Local government in South Africa 2004-2006, Official yearbook, Gaffney Group: Johannesburg, pp. 810-824, 2004.

[12] South Africa, Constitution of the Republic of South Africa Act, Act No 108 of 1996. Schedules 4 \& 5. Government Printer: Pretoria, 1996. 